\title{
GAMBARAN TINGKAT ANSIETAS PASIEN DAN KELUARGA PASIEN HEMODIALISIS
}

\author{
Livana PH ${ }^{1}$, Yulia Susanti ${ }^{1}$, Dewi Rahmawati ${ }^{1}$ \\ ${ }^{1}$ Program studi Ners, Sekolah Tinggi Ilmu Kesehatan Kendal \\ livana.ph@gmail.com
}

\begin{abstract}
ABSTRAK
Hemodialisis (cuci darah) merupakan suatu tindakan terapi pengganti ginjal yang telah rusak. Pasien yang menjalani hemodialisis mengalami masalah psikologis salah satunya yaitu ansietas. Ansietas terjadi dikarenakan kurangnya pengetahuan. Penelitian bertujuan untuk mengetahui gambaran tingkat ansietas, pasien dan keluarga pasien hemodialisis di RS Kendal. Metode penelitian menggunakan survey deskriptif kuantitatif.Alat ukur menggunakan 14 pertanyaan terkait ansietas pada kuesioner DASS (Depression Anxiety Stress Scale).Sampel penelitian berjumlah 60 pasien dan 60 keluarga pasien.Hasil penelitian menunjukkan bahwa mayoritas pasien dan keluarga pasien mengalami ansietas pada tingkat berat. Hasil penelitian ini direkomendasikan kepada peneliti selanjutnya agar dapat memberikan intervensi yang efektif untuk mengatasi ansietas pasien dan keluarga pasien hemodialisis.
\end{abstract}

Kata kunci: Ansietas, Pasien dan Keluarga pasien hemodialisis

\section{DESCRIPTION OF PATIENT ANSIETAS LEVELS AND FAMILY OF HEMODIALYSIS PATIENTS}

\begin{abstract}
Hemodialysis (dialysis) is an action therapy for kidney replacement that has been damaged. Patients who undergo hemodialysis experience psychological problems, one of which is anxiety. Anxiety occurs due to lack of knowledge. The study aims to describe the level of anxiety, patients and families of hemodialysis patients in Kendal Hospital. The research method used a quantitative descriptive survey. Measuring instruments used 14 questions related to anxiety on the DASS questionnaire (Depression Anxiety Stress Scale). The research samples were 60 patients and 60 patient families. The results showed that the majority of patients and families of patients experienced anxiety at a severe level. The results of this study were recommended to future researchers in order to be able to provide effective interventions to overcome the anxiety of patients and families of hemodialysis patients.
\end{abstract}

Keywords: Anxiety, Patients and Families of hemodialysis patients

\section{PENDAHULUAN}

Hemodialisis (cuci darah) merupakan suatu tindakan terapi pengganti ginjal yang telah rusak (Cahyaningsih, 2008). Terapi hemodialisis merupakan suatu cara yang dilakukan untuk mengeluarkan zat terlarut yang tidak di inginkan melalui difusi dan hemofiltrasi untuk mengeluarkan air yang terlarut yang tidak di inginkan (O'Callaghan, 2007). Hemodialisis ini dilakukan bila fungsi ginjal untuk membuang zatzat sisa metabolik yang beracun dan kelebihan cairan dari tubuh sudah sangat menurun (Vitahealth, 2008). World Health Organizatin (WHO) (2008), melaporkan bahwa 57 juta kematian di dunia disebabkan oleh penyakit Gagal Ginjal Kronik (GGK). Pasien GGK akan mengalami perasaan kehilangan karena kehidupan normalnya terganggu dengan kegiatan hemodialisis. Pasien dengan GGK cara penanganan yang umum dilakukan di Indonesia dengan hemodialisis (Alam \& Hadibroto, 2007).

Pasien yang menjalani hemodialisis mengalami beberapa masalah psikologis salah satunya yaitu ansietas (Wardani, PH, Sofa, 2015). Ansietas adalah kekhawatiran yang tidak jelas atau menyebar, yang berkaitan dengan perasaan tidak pasti dan tidak berdaya serta tidak memiliki objek spesifik.Ansietas dialami secara subjektif dan di komunikasikan secara interpersonal.Ansietas berbeda dengan rasa takut yang merupakan penilaian intelektual terhadap bahaya (Stuart, 2009). Pasien yang menjalani terapi hemodialisis yang mengalami ansietas sebesar $74,6 \%$. Ansietas terjadi dikarenakan kurangnya pengetahuan, besarnya biaya yang harus dikeluarkan dan adanya informasi yang mengatakan bahwa 
tindakan tersebut harus dilakukan seumur hidup Fallon, 2006 dalam (Slametiningsih, 2012). Hal ini di dukung oleh penelitian sebelumnya yang dilakukan oleh Sugianti (2011), di ruang hemodialisis Rumkital Dr. Ramelan Surabaya, mengenai lama dan frekuensi pasien GGK yang menjalani hemodialisis, pasien yang mengalami ansietas berat sebesar 33\%, ansietas sedang sebesar 45\%, ansietas ringan sebesar $22 \%$. Keluarga dapat menjadi faktor yang sangat berpengaruh dan dapat menentukan keyakinan dan nilai kesehatan individu tentang program pengobatan yang diterima. Hasil penelitian Jumaini (2014), menunjukkan bahwa tingkat ansietas keluarga yang anggota keluarganya menjalani terapi hemodialisis diketahui bahwa responden mengalami tingkat ansietas ringan sebanyak 12 orang $(23,1 \%)$ dan tingkat ansietas sedang sampai berat sebanyak 40 orang $(76,9 \%)$. Hasil studi pendahluan yang dilakukan di RS Kendal 7 dari 10 pasien yang dilakukan senwawancara mengatakan bahwa paisien sering mengalami susah tidur, tidak nafsu makan, dan sulit konsentrasi dalam melaksanakan aktifitas sehari-hari karena penyakit yang dideritaya. Hasil studi pendahuluan pada keluarga didapatkan 3 dari 5 keluarga pasien mengatakan bahwa dirinya menjadi khawatir dengan keadaan pasien karena pasien sering tidak mau makan, susah tidur, dan sering menunjukkan perilaku diam. Berdasarkan latarbelakang tersebut perlu dilakukan penelitian yang bertujuan untuk mengetahui gambaran ansietas pasien dan keluarga pasien hemodialisis.

\section{METODE}

Jenis penelitian ini menggunakan metode survey deskriptif kuantitatif. Alat yang digunakan dalam penelitian ini adalah kuesioner dengan kuesioner dengan 14 pertanyaan tentang tentang ansietas yang diambil dari Kuesioner DASS 42 (Depression Anxiety Stress Scale). Responden penelitian sebesar 60 pasien dan 60 keluarga pasien. Penelitian dilakukan di RS Kendal. Data dianalisis secara univarian dengan distribusi frekuensi.

\section{HASIL}

Hasil penelitian disajikan pada tabel berikut.

Tabel 2.

Karakteristik Keluarga Pasien Hemodialisis $(\mathrm{n}=60)$.

\begin{tabular}{|c|c|c|}
\hline Karakteristik & Frekuensi & Presentasi (\%) \\
\hline \multicolumn{3}{|l|}{ Jenis kelamin } \\
\hline Laki & 16 & 26.7 \\
\hline Perempuan & 44 & 73.3 \\
\hline \multicolumn{3}{|l|}{ Usia } \\
\hline 18-25 tahun & 6 & 10.0 \\
\hline 26-60 tahun & 45 & 75.0 \\
\hline$>60$ tahun & 9 & 15.0 \\
\hline \multicolumn{3}{|l|}{ Pekerjaan } \\
\hline Tidak Bekerja & 8 & 13.3 \\
\hline Bekerja & 52 & 86.7 \\
\hline \multicolumn{3}{|l|}{ Pendapatan } \\
\hline SUMR & 20 & 33.3 \\
\hline$\underset{V}{ } \mathrm{UMR}$ & 40 & 66.7 \\
\hline \multicolumn{3}{|l|}{ Hubungan Keluarga } \\
\hline Anak & 16 & 26.7 \\
\hline Istri & 30 & 50.0 \\
\hline Suami & 14 & 23.3 \\
\hline
\end{tabular}

Tabel 3.

Tingkat Ansietas Pasien dan Keluarga Pasien ( $\mathrm{n}=60)$

\begin{tabular}{lccccc}
\hline & Variabel & \multicolumn{2}{c}{ Pasien } & \multicolumn{2}{c}{ Keluarga } \\
\hline \multicolumn{1}{c}{ Tingkat Ansietas } & $\mathrm{f}$ & $\%$ & Frekuensi & $\%$ \\
\hline Berat & 29 & 48.3 & 41 & 68.3 \\
Sedang & 20 & 33.3 & 13 & 21.7 \\
Ringan & 11 & 18.3 & 6 & 10.0 \\
\hline
\end{tabular}

Tabel 1. 


\begin{tabular}{|c|c|c|}
\hline \multicolumn{3}{|c|}{ Karakteristik Pasien Hemodialisis $(\mathrm{n}=60)$} \\
\hline Karakteristik & Frekuensi & Persentasi (\%) \\
\hline \multicolumn{3}{|l|}{ Jenis kelamin } \\
\hline Laki-laki & 16 & 26.7 \\
\hline Perempuan & 44 & 73.3 \\
\hline \multicolumn{3}{|l|}{ Usia } \\
\hline 18-25 tahun & 7 & 11.7 \\
\hline 26-60 tahun & 44 & 73.3 \\
\hline$>60$ tahun & 9 & 15.0 \\
\hline \multicolumn{3}{|l|}{ Pekerjaan } \\
\hline Tidak Bekerja & 20 & 33.3 \\
\hline Bekerja & 40 & 66.7 \\
\hline \multicolumn{3}{|l|}{ Pendapatan } \\
\hline SUMR & 20 & 33.3 \\
\hline 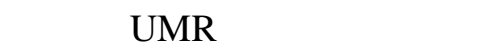 & 40 & 66.7 \\
\hline
\end{tabular}

Tabel 4.

Hasil Distribusi Tingkat Ansietas Klien dan Keluarga Klien Hemodialisis Berdasarkan Pernyataan Kuesioner Pernyataan Pasien Keluarga

\begin{tabular}{lcc}
\hline Saya merasa bibir saya sering kering & 21 & 18 \\
\hline $\begin{array}{l}\text { Saya mengalami kesulitan bernafas (misalnya: seringkali terengah-engah atau } \\
\text { tidak dapat bernafas padahal tidak melakukan aktivitas fisik sebelumnya) }\end{array}$ & 14 & 20 \\
\hline Saya merasa goyah (misalnya, kaki terasa mau 'copot') & 17 & 24 \\
\hline $\begin{array}{l}\text { Saya menemukan diri saya berada dalam situasi yang membuat saya merasa } \\
\text { sangat cemas dan saya akan merasa sangat lega jika semua ini berakhir }\end{array}$ & 7 & 3 \\
\hline $\begin{array}{l}\text { Saya merasa lemas seperti mau pingsan } \\
\text { Saya berkeringat secara berlebihan (misalnya: tangan berkeringat), padahal } \\
\text { temperatur tidak panas atau tidak melakukan aktivitas fisik sebelumnya }\end{array}$ & 2 & 3 \\
\hline Saya merasa takut tanpa alasan yang jelas & 11 & 14 \\
\hline Saya mengalami kesulitan dalam menelan & 15 & 21 \\
\hline $\begin{array}{l}\text { Saya menyadari kegiatan jantung, walaupun saya tidak sehabis melakukan } \\
\text { aktivitas fisik (misalnya: merasa detak jantung meningkat atau melemah) }\end{array}$ & 9 & 14 \\
\hline Saya merasa saya hampir panik & 5 & 16 \\
\hline $\begin{array}{l}\text { Saya takut bahwa saya akan 'terhambat' oleh tugas-tugas sepele yang tidak } \\
\text { biasa saya lakukan }\end{array}$ & 14 & 23 \\
\hline Saya merasa sangat ketakutan & 20 & 22 \\
\hline $\begin{array}{l}\text { Saya merasa khawatir dengan situasi dimana saya mungkin menjadi panik } \\
\text { dan mempermalukan diri sendiri }\end{array}$ & 10 & 16 \\
\hline Saya merasa gemetar (misalnya: pada tangan) & 8 & 12 \\
\hline
\end{tabular}

\section{PEMBAHASAN}

Hasil distribusi frekeuensi tingkat ansietas pada pasien dan keluarga pasien hemodialisis mayoritas dalam tingkatan berat, hal ini dapat diketahui bahwa sebagian besar responden mengalami ansietas dengan merasa sangat ketakutan dan responden selalu merasa takut akan terhambat oleh tugas-tugas sepele yang tidak biasa dilakukan oleh responden, sehingga hal tersebut memicu timbulnya ansietas yang tinggi pada keluarga pasien. Hasil penelitian ini didukung oleh penelitian Arosa (2014), tingkat ansietas keluarga yang anggota keluarganya menjalani terapi hemodialisis diketahui mengalami tingkat ansietas kategori sedang- berat sebanyak 40 orang $(76,9 \%)$. Penelitian tersebut juga di dukung dengan teori yang di ungkapkan oleh Viedebeck (2008), ansietas merupakan suatu perasaan berupa ketegangan, rasa ketakutan dan kekhawatiran yang muncul ketika berhadapan pada suatu keadaan yang tidak menyenangkan.

Ansietas merupakan aspek yang selalu ada dan menjadi bagian dari kehidupan. Ansietas yang terjadi akibat hemodialisis pasien yang dapat berdampak langsung pada penderita maupun keluarga. Adapun dampak yang ditimbulkan pada keluarga adalah secara emosional, sosial, fisik, 
dan keuangan.Secara emosional (psikologis) respon yang muncul salah satunya adalah ansietas. Hasil ini sesuai teori Stuart (2009) bahwa ansietas pada tingkat berat sangat mengurangi lapang persepsi individu. Seseorang dengan ansietas berat cenderung untuk memusatkan pada sesuatu yang terinci dan spesifik, serta tidak dapat berpikir tentang hal lain, sehingga memerlukan banyak pengarahan untuk dapat memusatkan pada suatu area yang lain. Hasil penelitian ini sejalan dengan penelitian Noorkasiani (2014) bahwa ansietas berat menyebabkan individu memiliki persepsi yang makin menyempit. Penelitian ini sesuai dengan penelitian PH, Keliat dan Putri (2016) bahwa intividu yang mengalami ansietas mengalami perubahan pada respons kognitif, afektif, fisiologis, perilaku, dan sosial.

\section{SIMPULAN DAN SARAN \\ Simpulan}

Berdasarkan hasil penelitian menunjukkan bahwa tingkat ansietas pasien dan keluarga pasien hemodialisis, mayoritas mengalami ansietas berat sebanyak 29 responden pasien $(48.3 \%)$, dan sebanyak 41responden keluarga(68.3\%).

\section{Saran}

Peneliti Selanjutnya diharapkan dapat memberikan intervensi yang efektif untuk mengatasi ansietas pasien dan keluarga pasien hemodialisis

\section{DAFTAR PUSTAKA}

Alam, S \& Hadibroto, I (2007). Gagal Ginjal. Jakarta: Gramedia

Arosa, Fyl Asro (2014). Hubungan Tingkat Pengetahuan Keluarga Tentang Hemodialisis dengan Tingkat Ansietas Keluarga Yang Anggota Keluarganya Menjalani Hemodialisis. Program Studi Ilmu Keperawatan Universitas Riau

Cahyaningsih, N. D (2008).Hemodialisis (cuci darah). Jogjakarta: Mitra Cendikia Press

Hurlock. (2010). Psikologi Perkembangan: Suatu Pendekatan Sepanjang Rentang Kehidupan: Edisi kelima. Jakarta : Erlangga.
Jumaini.(2014). Hubungan Tingkat Pengetahuan Keluarga Tentang Hemodialisis dengan Tingkat Ansietas Keluarga Yang Anggota Keluarganya Menjalani Hemodialisis. Program Studi Ilmu Keperawatan Universitas Riau. diperoleh dari http://download.portalgaruda.org/article.ph p? article $=186709 \& \mathrm{val}=6447 \&$ title $\quad$ pada tanggal 20 januari 2016.

O' Callaghan, C (2007).At a Glance Sistem Ginjal, edisi 2. Jakarta: Erlangga

Shanty, M (2011)."Silent Killer Disease" (Penyakit yang Diam-Diam Mematikan). Jogjakarta: Javalitera

Slametiningsih (2012).Pengaruh Logoterapi Individu Paradoxical Intention Terhadap Penurunan Ansietas Pada Pasien Gagal Ginjal Kronik Yang Menjalani Terapi Hemodialisis Di RS Cempaka Putih Jakarta Pusat.Program Studi Magister Keperawatan Peminatan Keperawatan Jiwa Depok diperoleh dari http://lontar.ui.ac.id/file?file=digital/20306 156-T30971+-+Pengaruh+logoterapi.pdf pada tanggal 18 November 2015

Stuart, Gail W (2009). Principles and Practice of Psyciatric Nursing, edisi 9. Philadelphia: Elsevier Mosby.

Videbeck, S.I (2008). Psychiatric of Nursing. Philadelphia: F.A

WHO.(2008). Integrated Chronic Disease Prevention and Control. www.who.int

Noorkasiani, Endang Banon ED. (2014). Efektifitas terapihipnotis lima jari untuk menurunkan tingkat ansietas pasien hipertensi. Jurnal; keperawatan volume 1 no 3. Hal 22-33, 2014.

PH, Livana. Keliatt, B.A. Putri, YSE. (2015) Penurunan Respons Ansietas Klien Penyakit Fisik dengan Terapi Generalis Ansietas di Rumah Sakit Umum. Jurnal Keperawatan Jiwa Volume 4 no 1 Mei 2016.https://jurnal.unimus.ac.id/index.php/J $\mathrm{KJ} /$ article/view/3896. 